\title{
Peptidome comparison following gastrointestinal digesta of bovine versus caprine milk serum
}

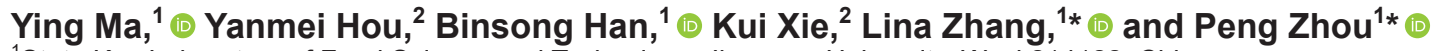 \\ ${ }^{1}$ State Key Laboratory of Food Science and Technology, Jiangnan University, Wuxi 214122, China \\ ${ }^{2}$ Ausnutria Hyproca Nutrition Co. Ltd., Changsha 410011, China
}

\begin{abstract}
Infant formula is used as a supplement for newborns. Although bovine milk-based infant formulas dominate the market, caprine milk-based infant formula has attracted increasing attention because of its lower allergenicity. This study compared the digestive peptidome of bovine and caprine milk serum proteins by using in vitro infant simulating conditions. The result showed that the degradation pattern of milk proteins was similar, whereas the digestive rates of milk proteins differed between bovine and caprine milks. Several proteins, such as $\alpha$-lactalbumin (LALBA), $\beta$-lactoglobulin (LGB), serum amyloid A protein (SAA1), glycosylationdependent cell adhesion molecule 1 (GLYCAM1), and lactotransferrin (LTF), released more peptides during digestion of caprine milk serum than during digestion of bovine milk serum; however, more peptides derived from $\alpha_{\mathrm{S}_{1}}$-casein $(\mathrm{CSN} 1 \mathrm{~S} 1$ ) were found in bovine digesta. In addition, antimicrobial-related peptides were mostly only found in caprine intestinal digesta. The results of this study may be useful in understanding the digestion characteristics of milk serum proteins and providing guidance on the improvement of infant formula.
\end{abstract}

Key words: bovine milk serum protein, caprine milk serum protein, digestion, peptidome

\section{INTRODUCTION}

Milk is the primary source of food for infants, which provides proteins, lipids, and carbohydrates to meet the nutrition and health requirements of infants. Infant formula may be used as a supplement or substitute for a number of reasons, and bovine milk products dominate the infant formula market. Recently, caprine milk-based

Received March 5, 2020.

Accepted August 23, 2020.

*Corresponding authors: zhoupeng@jiangnan.edu.cn and zhanglina@jiangnan.edu.cn infant formula has attracted increasing attention as an alternative because of its high digestibility and lower allergenicity to infants (Clark and Moro García, 2017).

There are some differences in nutrient composition between human, bovine, and caprine milks, especially in the protein fraction. The ratio of caseins to whey in bovine and caprine milks is much higher than that of human milk (Mayer and Fiechter, 2012; Chatterton et al., 2013). Most infant formulas are modified to match the human milk ratio by adding milk serum proteins (de Wit, 1998). Milk serum proteins not only provide essential amino acids (Nilsson et al., 2007), but also have some biological functions, such as immune system stimulation, nutrition system effects (Madureira et al., 2007), and fatty acid transport and synthesis (Lu et al., 2014). However, milk serum protein differs between bovine and caprine milk, which result in differences in the digestibility and biological function between the 2 species. First, the milk serum protein composition of bovine and caprine milk is different. For example, the concentration of the polymeric immunoglobulin receptor isoform 1 is significantly higher in caprine milk than in bovine milk (Hernández-Castellano et al., 2016). Second, the AA sequences of proteins are different in these 2 species. For instance, the AA sequence of bovine $\beta$-lactoglobulin (LGB) shows $5.6 \%$ nonhomology with caprine LGB based on Uniprot database (https://www .uniprot.org/). Moreover, 12 polymorphic variants of LGB have been found in bovine milk to date, whereas only 2 polymorphic variants are found in caprine LGB (Selvaggi et al., 2014). The genetic variability of proteins also leads to differences in AA sequences. Finally, bovine and caprine milk proteins differ in structure. It was found that the binding affinities of caprine $\alpha$-lactalbumin (LALBA) to monoclonal antibodies were different from bovine LALBA (Kaminogawa et al., 1989), which may indicate that the structure of LALBA differs in these 2 species.

Variations in milk composition may lead to differences in the digestibility of milk proteins between bovine and caprine species. Recently, several studies have reported 
the digestive properties of bovine and caprine milk. One study suggested that bovine and caprine caseins showed similar digestion profiles, but the peptide cleavage sites were different in the 2 species (Hodgkinson et al., 2019). Another study compared digestibility of bovine and caprine milk simulating gastric conditions of infants and young children, and found that caprine caseins were more sensitive to digestion than bovine caseins (Hodgkinson et al., 2018). Bovine milk digesta had a higher dipeptidyl peptidase IV inhibitory activity compared with caprine milk digesta (Tagliazucchi et al., 2018). Infant formula made with caprine milk forms smaller clots of protein and oil droplets compared with that made from bovine milk (Ye et al., 2019). Because these studies used whole milk to simulate in vitro digestion, the digestive properties of milk serum proteins are limited. Peptidomics is a relevant tool for assessing protein digestion; it can be used not only to trace released peptides but also to provide the biological activities of the identified peptides (Dupont, 2017). The objective of this study was to identify the peptides released from bovine and caprine milk serum proteins by simulated infant gastrointestinal digestion and compare the digestive peptidome of milk serum proteins between the 2 species.

\section{MATERIALS AND METHODS}

\section{Materials}

Fresh Holstein bovine milk was purchased from a local producer (Tianzi Dairy Co. Ltd., Wuxi, Jiangsu, China). Fresh Saanen caprine milk was purchased from a producer (Caiyang Husbandry Co. Ltd., Hangzhou, Zhejiang, China). Porcine pepsin (cat. no. P6887; enzyme activity $3,203 \mathrm{U} / \mathrm{mg}$ of protein), and porcine pancreatin (cat. no. P1750; $4 \times \mathrm{USP}$ ) were purchased from Sigma-Aldrich Chemical Company (St. Louis, MO). All the other chemicals used were of analytical grade.

\section{Milk Serum Preparation}

The separation of serum protein was based on a previous study with some modifications (Liao et al., 2011). Milk samples were centrifuged at $1,500 \times g$ for $10 \mathrm{~min}$ at $10^{\circ} \mathrm{C}$ (Heraeus Multifuge XIR, ThermoFisher Scientific, San Jose, CA). The pH of the obtained skim bovine milk and caprine milk were adjusted to 4.6 and 4.0 , respectively. The samples were kept at $4^{\circ} \mathrm{C}$ for $1 \mathrm{~h}$. They were centrifuged at $13,000 \times g$ for $30 \mathrm{~min}$ twice. Then the transparent liquid was collected and the bicinchoninic acid (BCA) assay kit (BCA protein assay kit, Thermo Scientific Pierce, Rockford, IL) was used to determine the milk serum protein concentration.

\section{SDS-PAGE}

We performed SDS-PAGE on the whole milk and milk serum samples. For each sample, $12.5 \mu \mathrm{g}$ was electrophoresed through $12 \%$ polyacrylamide gel. The gels were stained with Coomassie Blue R-250 and destained.

\section{In Vitro Gastrointestinal Digestion}

Digestion samples were prepared using a modified procedure (Liu et al., 2016; Su et al., 2017; Brodkorb et al., 2019). Briefly, the protein concentration of milk serum was adjusted to $5 \mathrm{mg} / \mathrm{mL}$. Then, the $\mathrm{pH}$ of both milk sera was adjusted to 4.0 and the sera were mixed with simulated gastric fluid (1:1 vol/vol, $22.76 \mathrm{U}$ of pepsin per mg of milk protein, $\mathrm{pH} 4.0,0.15 \mathrm{M} \mathrm{NaCl})$. The samples were incubated for $2 \mathrm{~h}$ at $37^{\circ} \mathrm{C}$. The $\mathrm{pH}$ of digesta was increased to 7 to terminate pepsinolysis. Subsequently, an equal volume of simulated intestinal fluid [pancreatin:protein ratio of 1:50 (wt/wt), $\mathrm{pH} 6.5$, $2 \mathrm{~m} M$ sodium taurocholate, $2 \mathrm{~m} M$ sodium glycodeoxycholate, $\left.50 \mathrm{mM} \mathrm{KH_{2 }} \mathrm{PO}_{4}\right]$ was added to the gastric digesta. Intestinal digestion was performed at $37^{\circ} \mathrm{C}$ for 2 h. The intestinal digested samples were heated at $100^{\circ} \mathrm{C}$ for $5 \mathrm{~min}$ and then stored at $-80^{\circ} \mathrm{C}$ for further analysis. For each sample, aliquots were taken after 0 and $2 \mathrm{~h}$ of gastric digestion and after $2 \mathrm{~h}$ of intestinal digestion. All digestive procedures were run in duplicate.

\section{Degree of Hydrolysis}

The degree of hydrolysis (DH) was measured using the standardized o-phthaldialdehyde (OPA) spectrophotometric assay (Mulet-Cabero et al., 2019). Trichloroacetic acid was added to the samples to a final concentration of $3.12 \%$ for insoluble protein precipitation. Then, the samples were centrifuged at $10,000 \times g$ for $30 \mathrm{~min}$. The supernatant was collected and filtered through a nylon membrane with a pore size of $0.22 \mu \mathrm{m}$ (Xinya Inc., Shanghai, China). The OPA reagent was prepared as following: $3.81 \mathrm{~g}$ of sodium tetraborate was added to $80 \mathrm{~mL}$ of distilled water. When it was dissolved, $88 \mathrm{mg}$ of dithiothreitol and $0.1 \mathrm{~g}$ of SDS were added and mixed. Finally, $80 \mathrm{mg}$ of OPA was dissolved in $3 \mathrm{~mL}$ of ethanol and added to the mixture, and the solution was made up to $100 \mathrm{~mL}$ with distilled water.

Standard L-leucine solution was used to make a calibration curve. Ten microliters of standard/sample was mixed with $200 \mu \mathrm{L}$ of OPA reagent. The mixtures were measured at $340 \mathrm{~nm}$ using a Multiskan Sky microplate spectrophotometer (Thermo Fisher Scientific, Karlsruhe, Germany) after standing for $15 \mathrm{~min}$. The calculation of $\mathrm{DH}$ was according to a previous study (Nielsen et al., 2001). 


\section{Extraction of Peptides}

Before injection, digested samples were precipitated by addition of $200 \mathrm{~g} / \mathrm{L}$ trichloroacetic acid (1:1 vol: vol; Nielsen et al., 2018). The supernatant from each sample was collected after centrifugation $(4,000 \times g$ for $10 \mathrm{~min}, 4^{\circ} \mathrm{C}$ ), and dithiothreitol was incorporated with each sample to a final concentration of $10 \mathrm{~m} M$ for 30 min at $56^{\circ} \mathrm{C}$. Next, iodoacetamide was added at a final concentration of $55 \mathrm{mM}$ and incubated for $45 \mathrm{~min}$ at $25^{\circ} \mathrm{C}$. After that, the samples were desalted using $\mathrm{C} 18$ columns and filtered with a $10-\mathrm{kDa}$ ultra-centrifugal filter. Peptide fractions were obtained after freeze-drying (LaboGene, Lynge, Denmark).

\section{Determination of Peptides}

Peptide analysis was performed on a Q-Exactive HF $\mathrm{X}$ (Thermo Scientific, Waltham, MA) equipped with an UltiMate 3000 UHPLC system (Thermo Scientific). Two micrograms of peptides was loaded onto a trap column $(300 \mu \mathrm{m} \times 5 \mathrm{~mm}, \mu$-Precolumn, Thermo Scientific) connected to an in-house packed RP C18 analytical column $(75 \mu \mathrm{m} \times 25 \mathrm{~cm}, 3-\mu \mathrm{m}$ particle). The liquid chromatography (LC) eluent was initially set to $95 \%$ solvent A (2\% acetonitrile and $0.1 \%$ formic acid) and $5 \%$ solvent B (98\% acetonitrile and $0.1 \%$ formic acid) at $300 \mathrm{~nL} / \mathrm{min}$. The linear gradient was designed as follows: $5 \%$ solvent B for $5 \mathrm{~min}, 5$ to $25 \%$ solvent B for 40 min, 25 to $35 \%$ solvent B for 5 min, 35 to $80 \%$ solvent

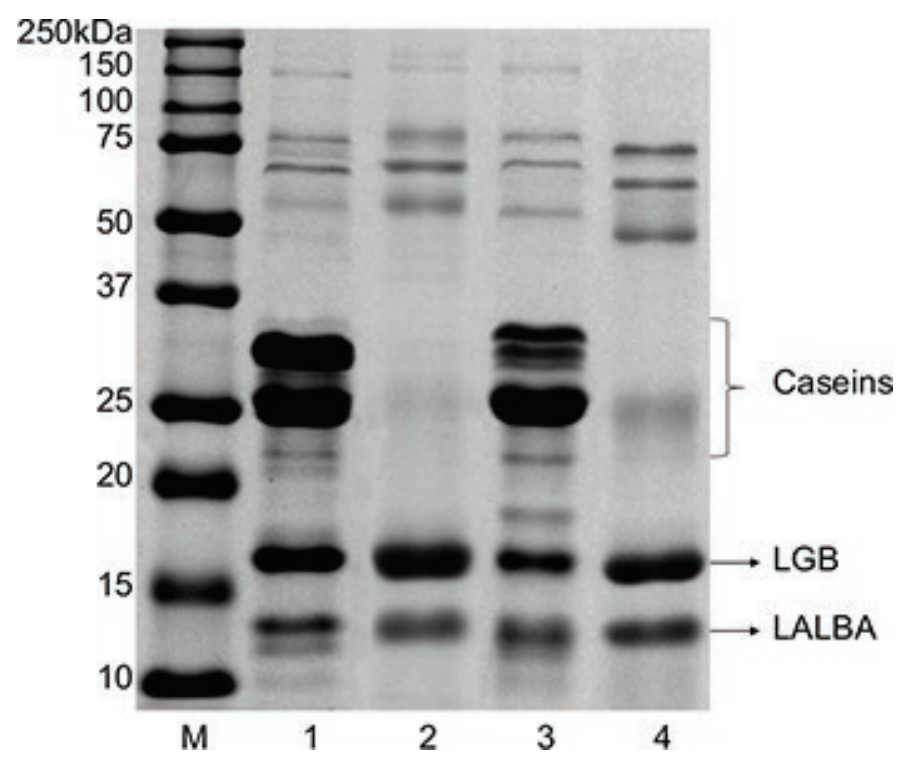

Figure 1. Sodium dodecyl sulfate-PAGE of whole milk proteins and milk serum proteins. $\mathrm{M}=$ molecular weight standard, lane $1=$ bovine whole-milk proteins, lane 2 = bovine milk serum proteins, lane 3 = caprine whole-milk proteins, and lane $4=$ caprine milk serum proteins. $\mathrm{LGB}=\beta$-lactoglobulin; LALBA $=\alpha$-lactalbumin.
B for $2 \mathrm{~min}$, and held in $80 \%$ solvent B for $2 \mathrm{~min}$. The mass scan was 350 to $1,500 \mathrm{~m} / z$ with a resolution of 60,000 , and the automatic gain control (AGC) target was set to $3 \mathrm{e}^{6}$. The tandem mass spectrometry (MS/ MS) scan was $100 \mathrm{~m} / z$ with a resolution of 15,000 ; the AGC target was set to $1 \mathrm{e}^{5}$.

\section{Data Analysis}

Raw files were analyzed using MaxQuant (1.5.3.30; https://maxquant.net/maxquant/) using 2 databases (Bos taurus, Capra genus) downloaded from Uniprot (https://www.uniprot.org/). The following parameters were used: enzyme $=$ unspecific; minimal peptide length $=7$; peptide mass tolerance $=4.5 \mathrm{ppm}$; fragment mass tolerance $=20 \mathrm{ppm}$; carbamidomethyl for fixed modification; oxidation of methionine and N-terminal for variable modifications. Maximum false discovery rates (FDR) were set to $1 \%$ on peptide spectrum match level. Peptides sharing the same AA sequence but with different modifications were considered different peptides for number counts and intensity.

\section{Statistical Analysis and Functional Analysis}

Peptides detected in 2 replicates can be considered identified, and the peptides not detected in both duplicates were deleted from the data. $\log _{2}$ scale transformation was performed in Perseus (https:// maxquant.net/perseus/), which was also used to carry out statistical analysis, including multiple ANOVA and 2 -samples $t$-test. The biological functions of identified peptides were analyzed according to Milk Bioactive Peptide Database (http://mbpdb.nws; Nielsen et al., 2017). Peptides in the samples with $100 \%$ homology to database peptides were reported. For DH, statistical analysis was performed using the independent-samples $t$-test in SPSS 24.0 (IBM Corp., Armonk, NY). Between different groups, $P<0.05$ was considered a significant difference.

\section{RESULTS}

\section{Extraction of Milk Serum Proteins}

The milk serum proteins of bovine and caprine milks were isolated by removing the fat layer and precipitating the caseins. The abundance of casein bands in milk serum decreased significantly after treatment, suggesting successful removal of caseins (Figure 1).

\section{Hydrolysis of Proteins}

Figure 2 shows the DH of milk serum samples before and after digestion. The $\mathrm{DH}$ increased in bovine and 
caprine milk serum samples during digestion. Significant statistical differences $(P<0.01)$ were observed in milk serum between the 2 species at the beginning and after $2 \mathrm{~h}$ of gastric digestion. A significant increase $(P$ $<0.01)$ in $\mathrm{DH}$ was observed in gastric digesta compared with the raw milk serum in both bovine and caprine species. In addition, DH continued to increase significantly $(P<0.01)$ from gastric digesta to intestinal digesta in both milk species.

\section{Identified Peptides and Proteins}

Figure 3 shows the Venn diagram of peptides identified in the 6 samples (peptides detected in 2 replicates were considered identified). In total, 5,676 unique peptides deriving from bovine and caprine milk serum proteins were identified (Figure $3 \mathrm{~A}$ ). Of the total number, 2,402 and 3,698 originated from bovine and caprine milk serum protein, respectively (Figure 3B, 3C). For both species, the number of identified peptides was much higher in gastric digesta than in intestinal digesta. Overall, 39 and 101 overlapping peptides were identified in fresh milk serum and gastric and intestinal digesta of bovine and caprine milks, respectively.

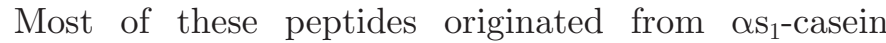
(CSN1S1), $\beta$-casein (CSN2), and LGB in bovine milk serum samples (Supplemental Table S1; https:/ /doi.org/10.3168/jds.2020-18471), whereas they were from CSN1S1, $\alpha_{2}{ }_{2}$-casein (CSN1S2), CSN2, BLG, and serum amyloid A protein (SAA1) in caprine milk serum samples (Supplemental Table S2; https://doi.org/ 10.3168/jds.2020-18471). These peptides were thought to be survivors of milk serum peptides after gastrointestinal digestion.

The protein origin of identified peptides is given in Figure 4. Proteins were divided into the following cat-

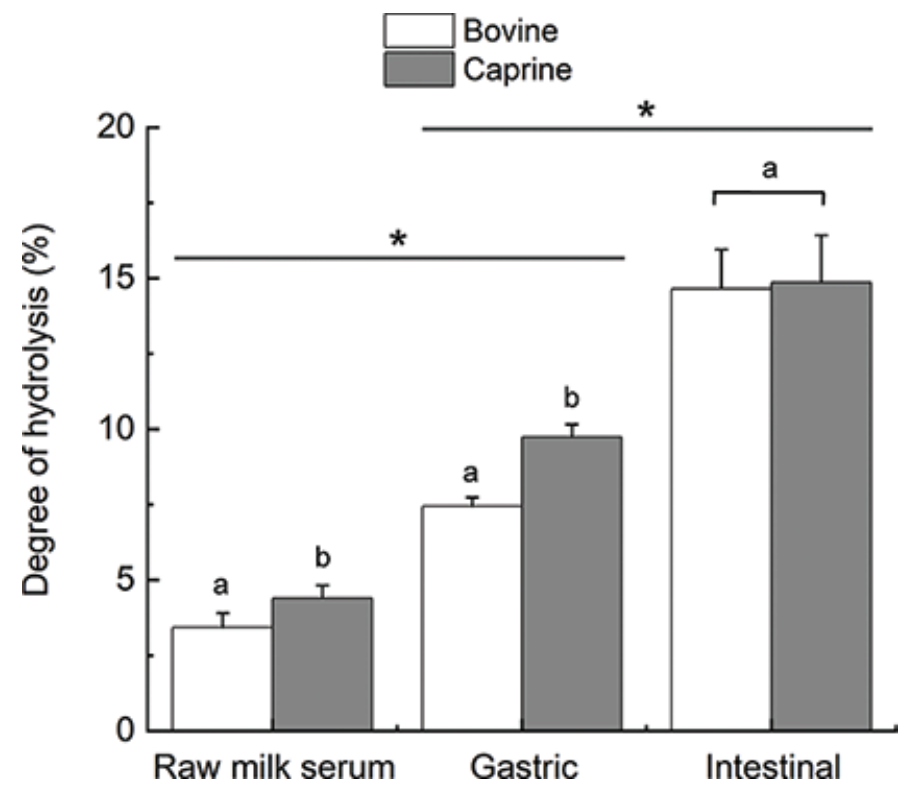

Figure 2. Degree of hydrolysis of bovine and caprine milk serum before and after gastrointestinal digestion. ${ }^{*}$ Results at different digestion times are significantly different $(P<0.01)$. Different letters $(\mathrm{a}, \mathrm{b})$ indicate a significant difference $(P<0.01)$ between species after their respective digestion period. Error bars represent SD.

egories: major milk serum proteins (LALBA, LGB), caseins [CSN1S1, CSN1S2, CSN2, and $\kappa$-casein (CSN3)], minor proteins [SAA1, lactotransferrin (LTF), glycosylation-dependent cell adhesion molecule 1 (GLYCAM1), lactoperoxidase (LPO), polymeric immunoglobulin receptor (PIGR), osteopontin (SPP1), butyrophilin subfamily 1 member A1 (BTN1A1)], and other proteins. The number of identified peptides from caseins and major milk serum proteins made up a large part of the total identified peptides. In addition, CSN2 and LGB were the dominant proteins in
A

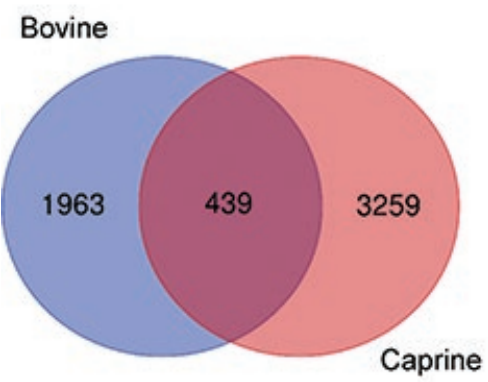

B

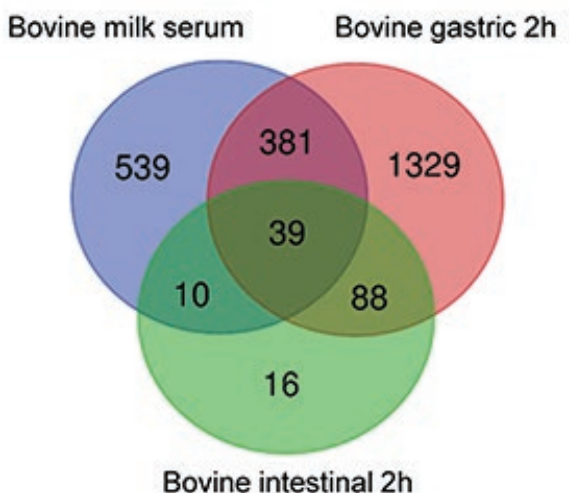

C

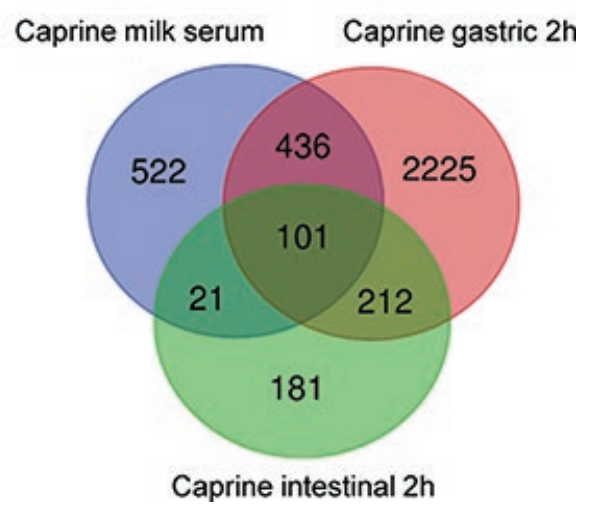

Figure 3. Venn diagram showing the unique peptides identified in bovine and caprine milk serum before and after a 2-h gastrointestinal digestion. 
these 2 species, respectively. In contrast, the number of endogenous peptides derived from SAA1 was much higher in caprine than in bovine milk serum. The number of peptides derived from LPO and BTN1A1 was higher in gastric digesta of caprine milk than of bovine milk, and the number of peptides derived from SAA1, GLYCAM1, and LTF was higher in both gastric and intestinal digesta of caprine milk than in those of bovine milk.

\section{Quantitative Level of Identified Peptides}

The exclusively identified peptides (i.e., only identified in one species, caprine or bovine) in gastric and intestinal digesta in bovine and caprine milk serum are shown in Figure 5. In general, the total number of exclusive peptides in caprine milk serum digesta was much higher than that in bovine milk serum digesta. However, the proteins of origin of exclusive peptides varied between bovine and caprine milk serum. For instance, the number of exclusive peptides derived from LALBA, CSN2, SAA1, GLYCAM1, LPO, PIGR, LTF, and BTN1A1 was greater in caprine than in bovine milk serum, whereas exclusive peptides from CSNS1, CSNS2, CSN3, and LGB were relatively more numerous in bovine gastric digesta than in caprine gastric digesta. With respect to the number of exclusive peptides in intestinal digesta, we found only a few peptides in bovine intestinal digesta (16) and many more (181) derived from proteins including LGB, SAA1, and LTF in caprine intestinal digesta (Figure 5).

We analyzed the overlapping peptides between groups using the 2 -samples $t$-test (Figure 6). The peptide intensity was used to determine the statistical significance of
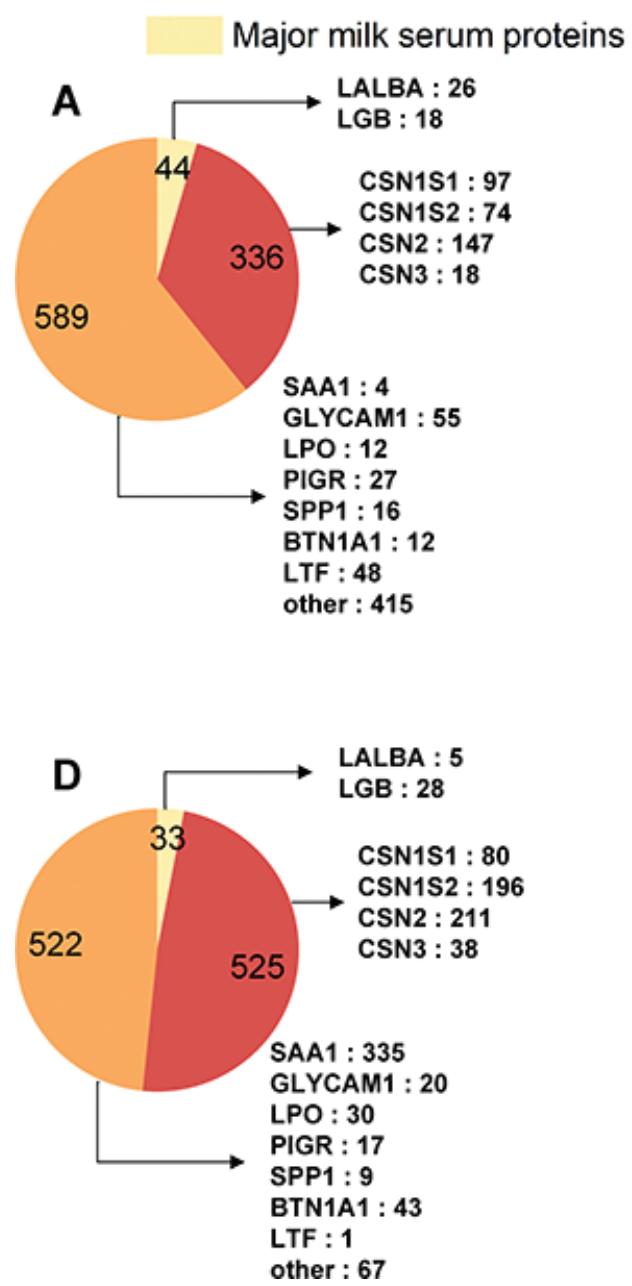

Figure 4. Distribution of protein origin for the peptides detected before and after gastrointestinal digestion in bovine milk serum (A), in bovine gastric digesta (B), in bovine intestinal digesta (C), in caprine milk serum (D), in caprine gastric digesta (E), and in caprine intestinal digesta $(\mathrm{F}) . \mathrm{LALBA}=\alpha$-lactalbumin, $\mathrm{LGB}=\beta$-lactoglobulin, CSN1S1 $=\alpha_{\mathrm{S} 1}$-casein, CSN1S2 $=\alpha_{\mathrm{S} 2}$-casein, $\mathrm{CSN} 2=\beta$-casein, $\mathrm{CSN} 3=\kappa$-casein, SAA1 = serum amyloid A protein, GLYCAM1 = glycosylation-dependent cell adhesion molecule 1, LPO = lactoperoxidase, PIGR = polymeric immunoglobulin receptor, SPP1 = osteopontin, BTN1A1 = butyrophilin subfamily 1 member A1, LTF = lactotransferrin.

\section{Minor milk serum proteins}
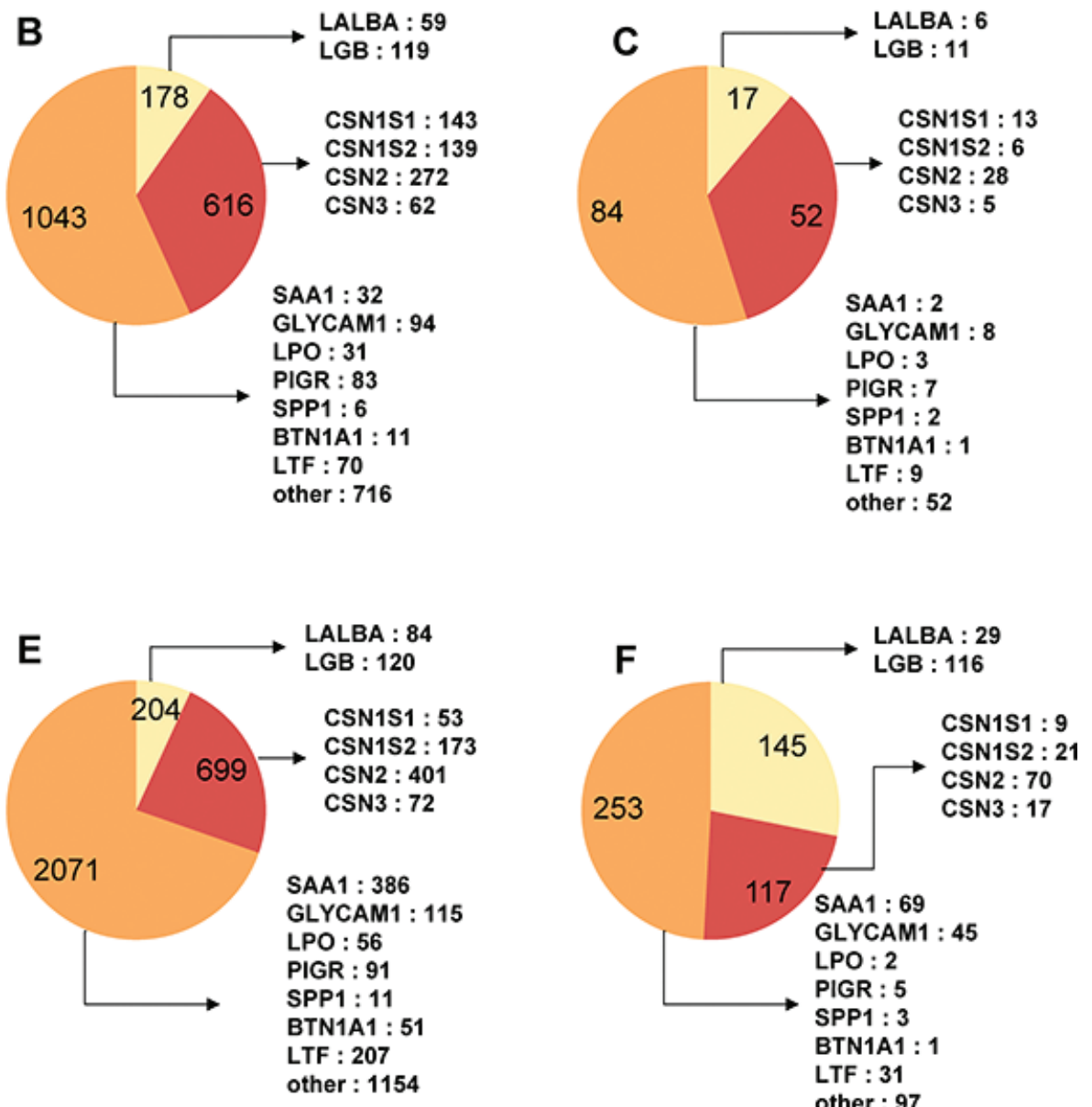

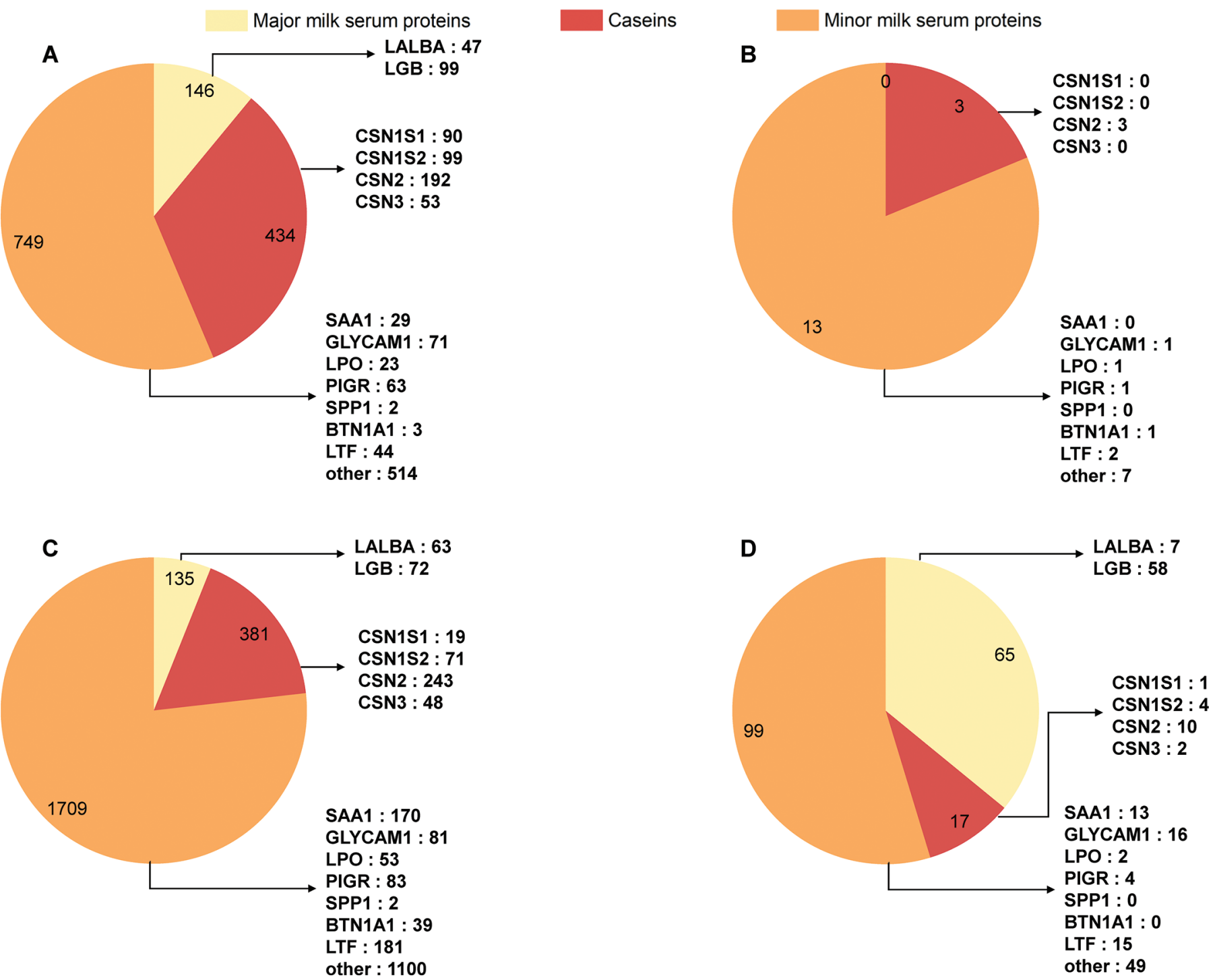

Figure 5. Exclusively identified peptides in gastric and intestinal digesta between bovine and caprine milk serum in bovine gastric digesta $(\mathrm{A})$, in bovine intestinal digesta $(\mathrm{B})$, in caprine gastric digesta $(\mathrm{C})$, and in caprine intestinal digesta $(\mathrm{D})$. LALBA $=\alpha$-lactalbumin, LGB $=$ $\beta$-lactoglobulin, CSN1S1 $=\alpha_{\mathrm{S}_{1}}$-casein, CSN1S2 $=\alpha_{\mathrm{S} 2}$-casein, $\mathrm{CSN} 2=\beta$-casein, CSN3 $=\kappa$-casein, SAA1 $=$ serum amyloid A protein, GLYCAM1 $=$ glycosylation-dependent cell adhesion molecule $1, \mathrm{LPO}=$ lactoperoxidase, $\mathrm{PIGR}=$ polymeric immunoglobulin receptor, $\mathrm{SPP} 1=$ osteopontin, BTN1A1 = butyrophilin subfamily 1 member A1, LTF = lactotransferrin.

peptides, and significantly different peptides are shown as red (upregulated) and green dots (downregulated) based on the criteria of a fold change $>1.5$ or $<0.67$ and $P<0.05$. A total of 147 peptides were downregulated and 32 were upregulated in the bovine gastric group compared with the bovine milk serum group; 26 peptides were downregulated and 8 upregulated in the bovine intestinal group compared with the bovine milk gastric group. For caprine milk serum, 91 peptides were downregulated and 41 upregulated in the gastric group compared with the milk serum group (Table 1 ). A total of 81 peptides were downregulated and 52 were upregu- lated in the caprine intestinal group compared with the caprine gastric group. Of the upregulated peptides in gastric digesta compared with milk serum, the number of peptides derived from CSN1S2, CSN2, and SAA1 was much higher in caprine than in bovine milk serum; in contrast, the number of peptides corresponding to LTF in milk serum was much higher in bovine than in caprine milk serum (Table 1). With respect to the significantly different peptides in intestinal and gastric groups, the number differed between the species, including peptides derived from CSN1S1, LALBA, CSN2, GLYCAM1, and SAA1 (Table 1). 
A
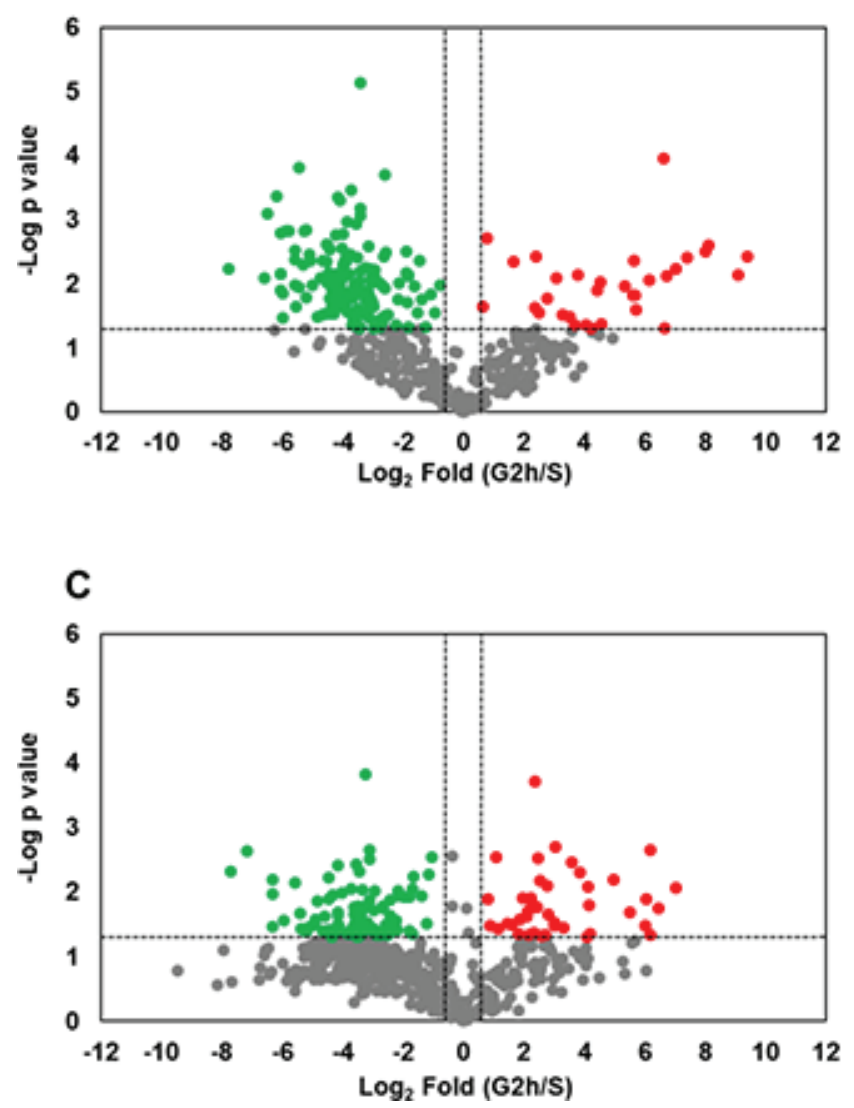

B

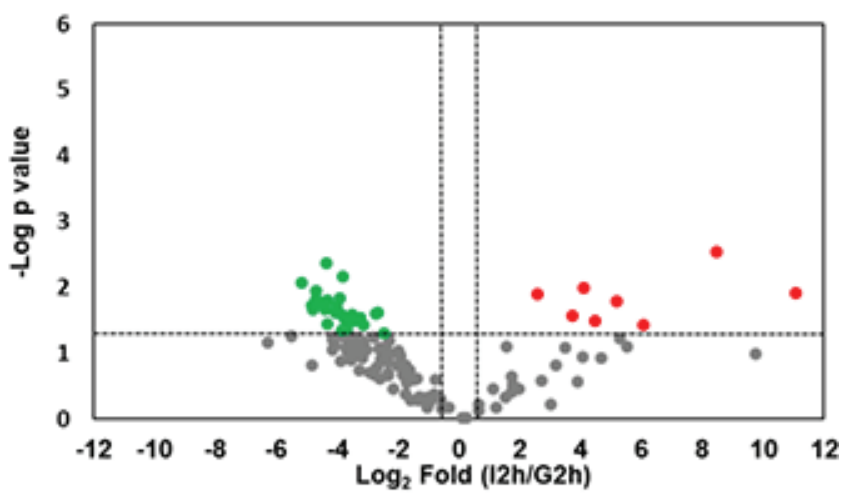

D

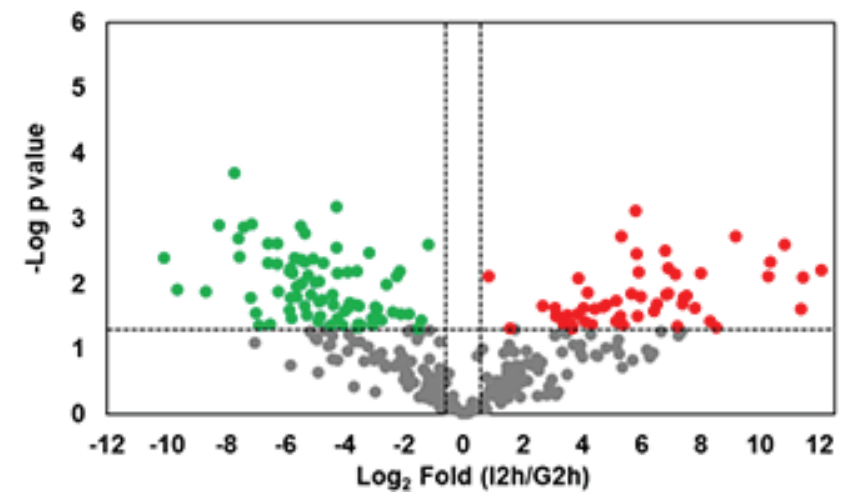

Figure 6. Volcano plots of differential peptides in bovine gastric group versus bovine milk serum group (A), bovine intestinal group versus bovine gastric group (B), caprine gastric group versus caprine milk serum group (C), and caprine intestinal group versus caprine gastric group (D). Red and green dots represent upregulated and downregulated peptides, respectively. $\mathrm{S}=$ milk serum sample, $\mathrm{G}=$ gastric sample, $\mathrm{I}=$ intestinal sample; $2 \mathrm{~h}$ represents 2 -h digestion.

The profile of peptide release over time across the 2 species is presented in Figure 7. The peptides originating from LALBA in bovine and caprine serum before digestion were different (Figure 7A). The peptides primarily originated from 2 sections of the caprine LALBA sequence, at AA positions $\mathrm{f} 72-79$ and f112-122. The endogenous peptides in bovine LALBA were primarily from 2 large segments (f20-78, f105-137). Although the peptide sequences in bovine and caprine LALBA after gastric digestion covered almost the entire protein, the abundance of peptides was higher in caprine than in bovine gastric digesta, particularly for sequences f20-49 and f108-136. The endogenous peptides of bovine LGB primarily originated from 4 sections, at AA f19-37, f47-72, f92-100, and f140-175 (Figure 7B). The sequences of the endogenous peptides of LGB were different in caprine milk serum than in bovine milk serum, which were dominated by f20-38, f51-60, and f76-122. The overlap in peptides found in intestinal digesta and entire protein was greater in caprine than in bovine samples.

\section{Bioactivity of Peptides After Simulated Gastrointestinal Digestion}

Tables 2 and 3 display bioactive peptides of bovine and caprine milk serum after simulated gastrointestinal digestion. Of all the identified peptides, 41 and 30 peptides of bovine and caprine milk serum were found to have bioactivities, including angiotensin-converting enzyme (ACE) inhibition and antimicrobial functionalities. The 10 peptides common to these 2 species are noted in Tables 2 and 3. Of these common proteins, 5 were derived from CSN2 (ACE-inhibitory, antimicrobial, and immunomodulatory activities), 2 from LALBA (dipeptidyl peptidase IV inhibitory activity), 2 from LGB (ACE-inhibitory activity), 1 from CSN1S2 (antimicrobial activity). Antimicrobial and 
Table 1. The number of differential peptides (down- or upregulated) between bovine and caprine milk serum in fresh milk serum, gastric digesta, and intestinal digesta

\begin{tabular}{|c|c|c|c|c|c|c|c|c|}
\hline Protein & \multicolumn{2}{|c|}{$\begin{array}{l}\text { Bovine gastric group } \\
\text { vs. bovine milk } \\
\text { serum group }\end{array}$} & \multicolumn{2}{|c|}{$\begin{array}{l}\text { Bovine intestinal } \\
\text { group vs. bovine } \\
\text { gastric group }\end{array}$} & \multicolumn{2}{|c|}{$\begin{array}{l}\text { Caprine gastric group } \\
\text { vs. caprine milk } \\
\text { serum group }\end{array}$} & \multicolumn{2}{|c|}{$\begin{array}{l}\text { Caprine intestinal } \\
\text { group vs. caprine } \\
\text { gastric group }\end{array}$} \\
\hline LALBA & 2 & 1 & 0 & 0 & 0 & 0 & 9 & 2 \\
\hline LGB & 2 & 0 & 5 & 0 & 0 & 0 & 6 & 17 \\
\hline CSN1S1 & 22 & 1 & 3 & 0 & 11 & 1 & 1 & 0 \\
\hline CSN3 & 2 & 1 & 1 & 0 & 1 & 2 & 3 & 0 \\
\hline SAA1 & 1 & 0 & 1 & 0 & 32 & 15 & 10 & 10 \\
\hline GLYCAM1 & 8 & 3 & 1 & 0 & 0 & 3 & 8 & 5 \\
\hline LPO & 2 & 0 & 0 & 0 & 1 & 0 & 0 & 0 \\
\hline PIGR & 6 & 2 & 2 & 1 & 0 & 0 & 1 & 0 \\
\hline SPP1 & 2 & 0 & 0 & 0 & 2 & 0 & 1 & 0 \\
\hline BTN1A1 & 5 & 1 & 0 & 0 & 2 & 1 & 0 & 0 \\
\hline
\end{tabular}

${ }^{1} \mathrm{LALBA}=\alpha$-lactalbumin; LGB $=\beta$-lactoglobulin; CSN1S1 $=\alpha_{\mathrm{S} 1}$-casein; CSN1S2 $=\alpha_{\mathrm{S} 2}$-casein; CSN2 $=\beta$-casein; CSN3 $=\kappa$-casein; SAA1 $=$ serum amyloid A protein; GLYCAM1 = glycosylation-dependent cell adhesion molecule 1; LPO = lactoperoxidase; PIGR = polymeric immunoglobulin receptor; SPP1 = osteopontin; BTN1A1 = butyrophilin subfamily 1 member A1; LTF = lactotransferrin.

ACE-inhibitory peptides were found in bovine caseins; however, no bioactive peptides were found in caprine CSNS1 milk serum or gastrointestinal digesta samples. Eleven bioactive peptides were found in caprine intestinal digesta samples, whereas only 3 were identified in bovine intestinal digesta.

\section{DISCUSSION}

Although the protein digestibility of whole milk between species has been reported previously, this is the first study to investigate the peptidome between bovine and caprine species based on milk serum samples in an in vitro infant digestion system. In total, we identified 5,676 peptides in bovine $(2,402)$ and caprine $(3,698)$ samples, which is much higher than the number of peptides (over 350) previously identified in bovine and caprine milk from simulated infant gastric digestion (Hodgkinson et al., 2019), and much higher than the number of peptides (384) identified in bovine milk after in vitro standardized gastro-pancreatic digestion (Tagliazucchi et al., 2016). The higher number of peptides identified can likely be attributed to sample preparation. In this study, we used the milk serum protein of 2 species to mimic infant digestion, which removed the influence of relatively high abundant milk proteins (caseins). Therefore, the number of digested peptides was relatively higher compared with digesta from whole milk. On the other hand, tracing the dynamics of digestion from fresh milk serum to intestinal digestion also probably explained the higher number of identified pep- tides in this study. For instance, a previous study only detected peptides in gastric samples (Hodgkinson et al., 2019), whereas our study used milk serum samples, gastric samples, and intestinal samples to comprehensively demonstrate the endogenous peptides and peptides released from gastrointestinal tracts. Another reason why we identified more peptides could be attributed to the LC-MS/MS analysis. In this study, we used Q Exactive HF MS/MS for analysis, whereas the cited articles mentioned above used maXis impact HD Q-TOF mass spectrometer. In addition, we used Bos taurus and Capra genus databases when comparing different species. The database used for matching may explain the differences in the numbers of identified peptides between species. At the beginning of digestion, more peptides were identified in caprine than in bovine milk serum samples (Figure 3), which may explain why high $\mathrm{DH}$ values were obtained in raw caprine milk serum samples (Figure 2). The number of peptides increased from milk serum samples to gastric samples in both species, which agrees with the findings of a previous study on gastric digestion in term infants (Dallas et al., 2014). The DH results from milk serum samples to gastric samples show the similar trend in both species (Figure 2). In addition, both the number of identified peptides (Figure 3 ) and the DH values (Figure 2) were higher in caprine than in bovine gastric digesta, which indicates that caprine milk serum proteins have a higher digestibility during gastric digestion. A decrease in peptide counts from gastric samples to intestinal samples was observed in both species. This was probably related 
A

BOVINO LALBA

Caprine LALBA

Bovino S

Caprine 8

Bovine G2h

Caprino Ga

Covine $12 \mathrm{~h}$

Bovino LALBA

Caprine LALBA

Bovine S

Coprine S

Bovine Gah

Bovine $12 \mathrm{~h}$

Caprine $12 \mathrm{~h}$

Bovine LALBA

Caprine LALBA

Bovino S

Caprine S

Bovine G2h

Covino $12 \mathrm{~h}$

Bovno izh

B

Bovine LGB

Bovine $\mathrm{S}$

Bovine G2h

Caprine G2

Bovine $12 \mathrm{~h}$

Caprine 12h

Bovine LGB

Caprine LGB

Bovine $\mathrm{S}$

Bovine G2h

Caprine G2h

Bovine $12 \mathrm{~h}$

Caprine $12 h$

Bovine LGB

Caprine LGB

Bovine $\mathrm{S}$

Bavine G2h

Bovine $12 \mathrm{~h}$
Coprine $12 \mathrm{~h}$

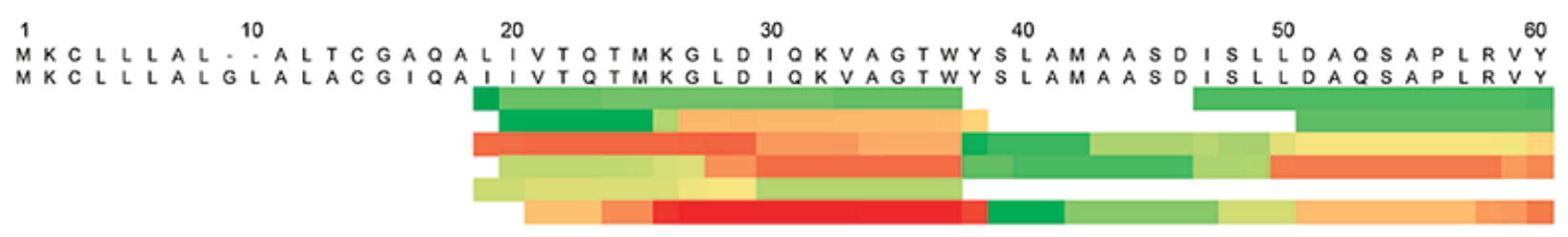

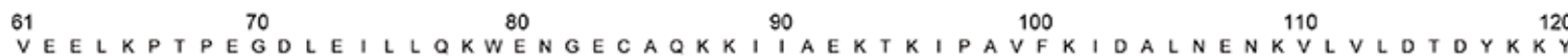
VEELKPTPEGNLE I L L QKWENGECAQKKI I AEKTKI PAVFKIDALNENKVLVLDTDYKKY

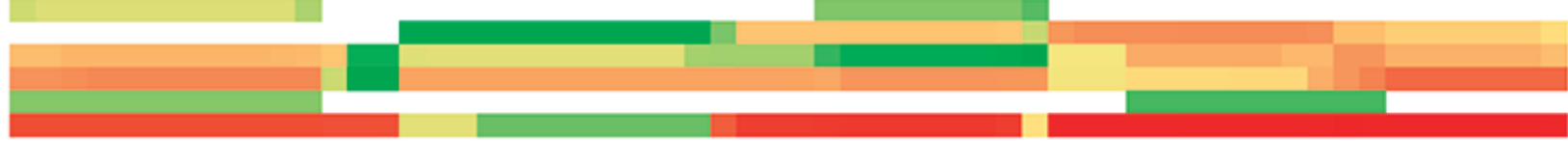
121

140

LE M E A PEQSLACQCLVRTPEVDDEALEKFDKALKALPMHIRLSFNPTOLEE Q R H I N

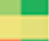

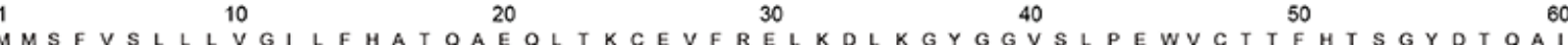
$M M S F V S L L L V G I L F H A T Q A E Q L T K C E V F Q K L K D L K D Y G G V S L P E W V C T A F H T S G Y D T Q A I$

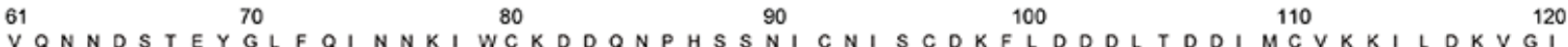

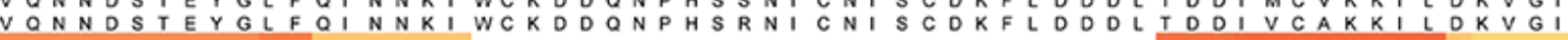
N Y WL A H K A L C 130 N Y WLAHKALCSEKLDQWLCEKL
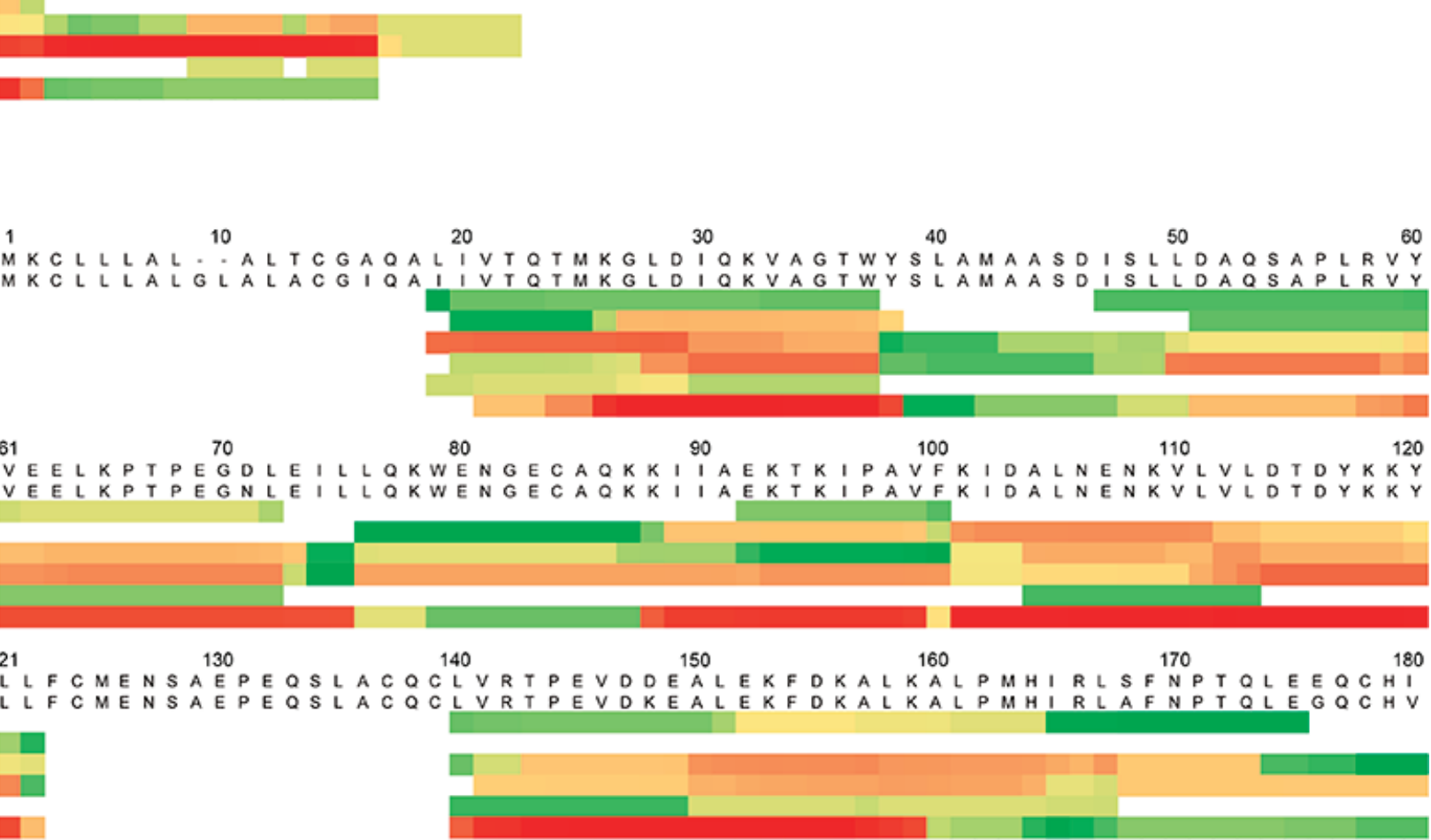

Figure 7. Schematic presentation of peptides formed before and after gastrointestinal digestion for (A) $\alpha$-lactalbumin (LALBA) and (B) $\beta$-lactoglobulin (LGB). Green indicates low relative abundance and red indicates high relative abundance of detected AA found in peptides found in digesta samples. $\mathrm{S}=$ milk serum sample, $\mathrm{G}$ = gastric sample, $\mathrm{I}=$ intestinal sample; $2 \mathrm{~h}$ represents 2-h digestion.

to a limitation of the method because our approach could only identify peptides longer than $7 \mathrm{AA}$; short peptides released after intestinal digestion were not detected in this study. Therefore, an increase in $\mathrm{DH}$ was observed from gastric samples to intestinal samples in both species (Figure 2), which is consistent with results of a previous study (Tagliazucchi et al., 2018).

\section{Peptides Derived from Major Milk Proteins}

Although most of the caseins in the milk were removed, a large number of peptides derived from caseins were identified in all samples. This could be due to endogenous casein peptides and free caseins (caseins not in the form of micelles) present in milk serum (Fig- 
ure 1). Another reason for the high number of peptides from caseins in gastric digesta is likely the different digestibility between caseins and milk serum proteins. Their flexible and open structure makes free caseins more sensitive to proteolysis (Dupont et al., 2010), and the rapid degradation of caseins has been reported in a previous study (Picariello et al., 2010). The different amount of caseins in milk serum of these 2 species may be due to the distinct casein micelle structure. The casein micelles in these 2 species have different average sizes, protein compositions, and levels of hydration (Ingham et al., 2018). Peptides from CSN1S1 and CSN2 were present in high proportions in bovine milk serum, whereas peptides from CSN1S2 and CSN2 had high abundance in caprine milk serum, which agrees with a previous study (Tamime et al., 2011). Of the unique peptides of bovine gastric digesta, the number of peptides derived from CSN1S1 and CSN1S2 were higher in bovine than in caprine. In contrast, the number of unique peptides derived from bovine CSN2 was lower than that from caprine CSN2. A previous study verified that sequence coverage for bovine caseins (CSN1S1, CSN2S2, CSN2) after gastric digestion was higher than that for caprine caseins (Hodgkinson et al., 2019). These results may indicate that the extent of gastric digestion of CSN1S1 and CSN1S2 is higher in bovine than in caprine milk. On the other hand, more peptides originating from CSN2 were observed to increase or decrease significantly in the caprine intestinal group compared with the caprine gastric group, suggesting that caprine

Table 2. Bioactivity of peptides before and after gastrointestinal digestion in bovine milk serum

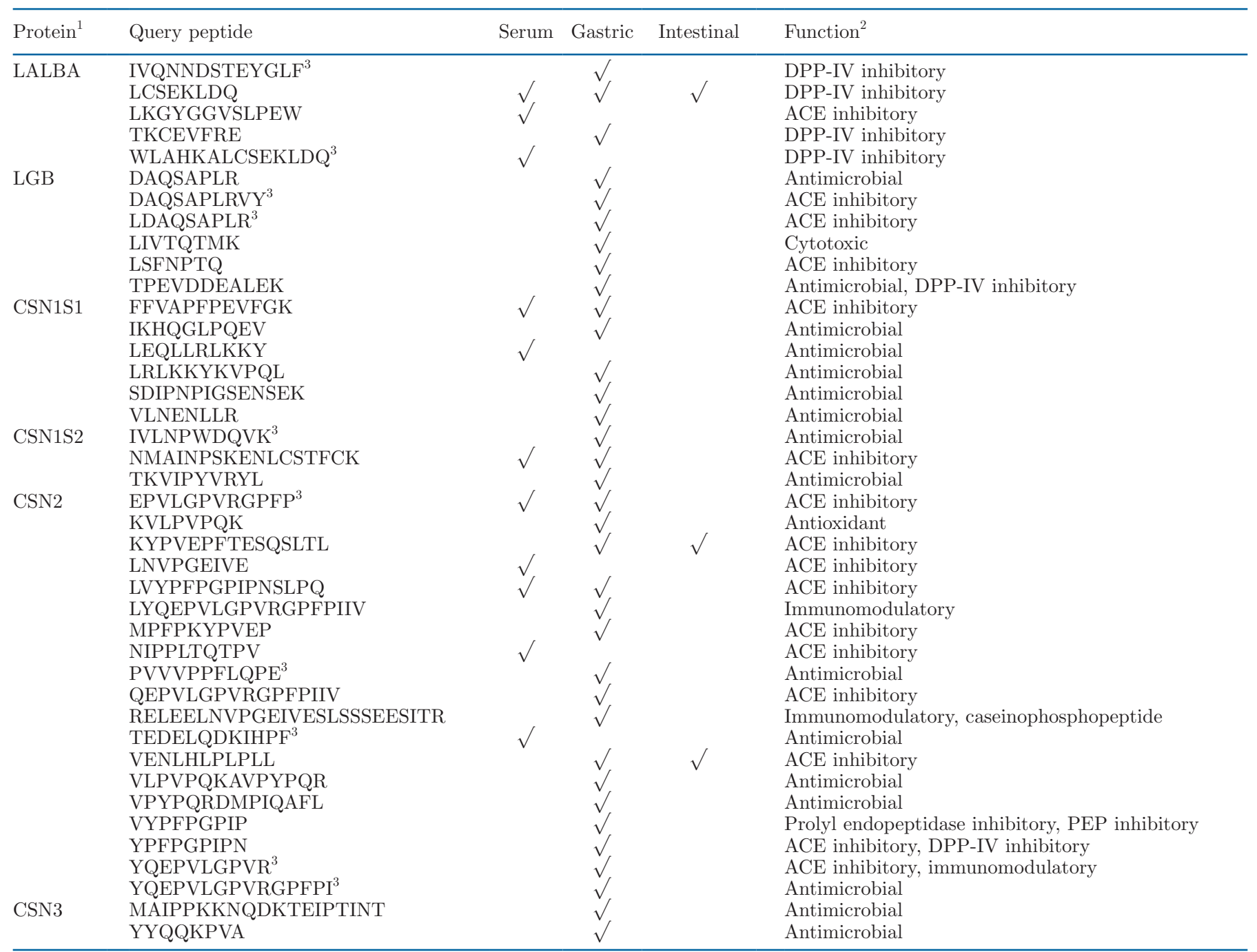

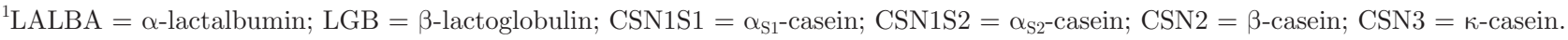

${ }^{2} \mathrm{DPP}-\mathrm{IV}=$ dipeptidyl peptidase IV; ACE = angiotensin-converting enzyme; PEP = prolyl oligopeptidase.

${ }^{3}$ The 10 peptides common to both bovine and caprine samples. 
Table 3. Bioactivity of peptides before and after gastrointestinal digestion in caprine milk serum

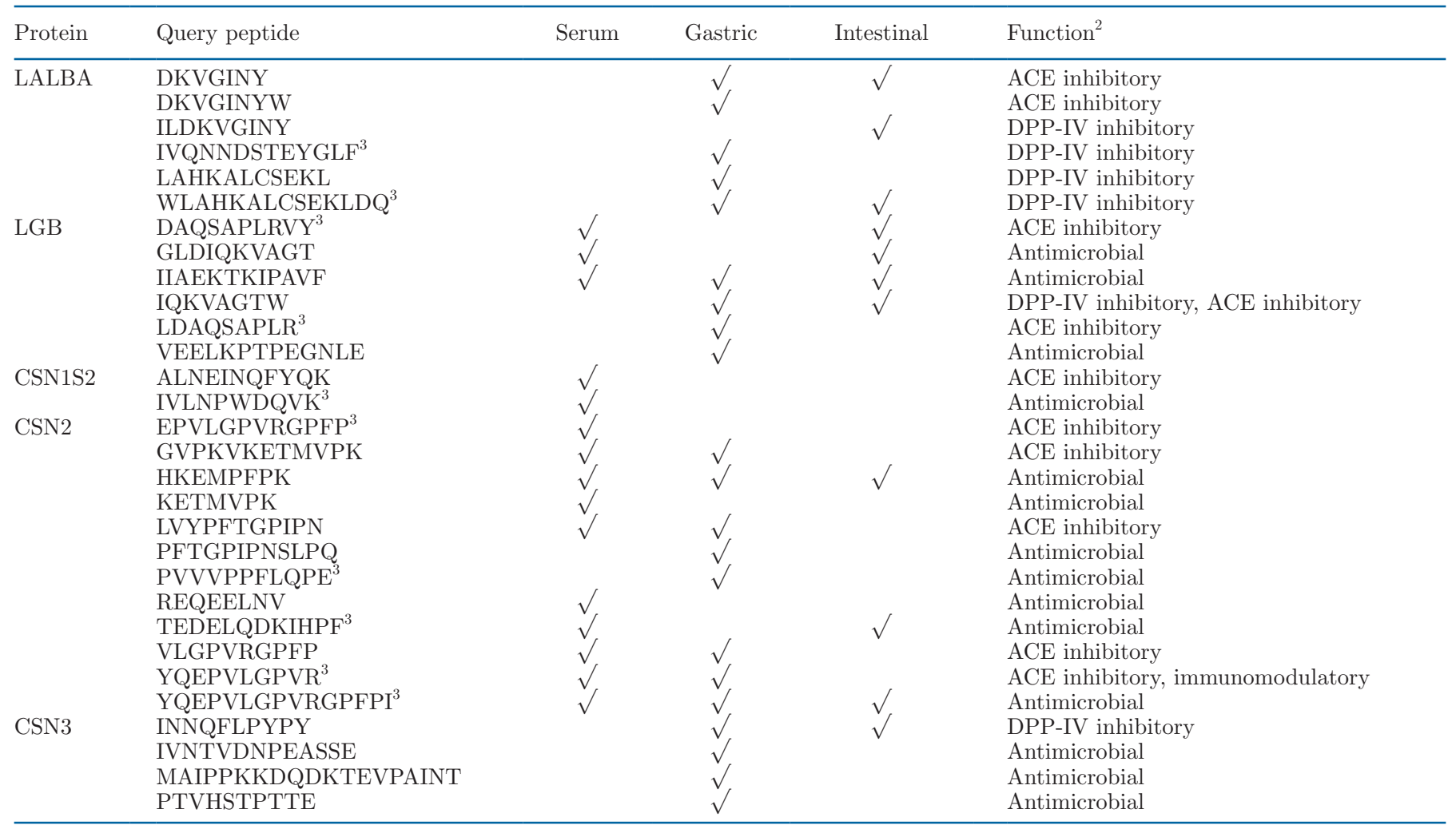

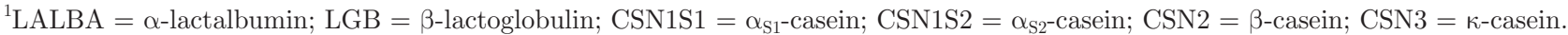

${ }^{2} \mathrm{DPP}-\mathrm{IV}=$ dipeptidyl peptidase IV; ACE = angiotensin-converting enzyme.

${ }^{3}$ The 10 peptides common to both bovine and caprine samples.

CSN2 is further digested in the small intestine. Identifying a bioactive peptide in the gastrointestinal tract is not enough to demonstrate its biological effect. Some peptides need to pass through the intestinal epithelium to exert their activity. However, peptides might be hydrolyzed by endogenous peptidases (Dupont, 2017). It is meaningful to focus on peptides that are active in the gut with no need to be absorbed. In addition, CSN2 is the most important precursor of peptides, including some functional peptides. In caprine intestinal samples, 3 peptides originating from CSN2 have antimicrobial activity. The presence of these antimicrobial peptides in the gut may be important to prevent gastrointestinal infections in infants (Dallas et al., 2013).

In addition to caseins, a large number of peptides derived from LALBA and LGB were also identified. More digested peptides from caprine LALBA and LGB were found during gastrointestinal digestion. Caprine LGB is digested faster than bovine LGB during in vitro digestion (Almaas et al., 2006), which was consistent with our study. Despite the number of identified peptides, the relative abundance of peptides from LALBA and LGB was higher in caprine than in bovine milk serum digesta (Figure 7), indicating higher digestibility of LALBA and LGB in caprine milk than in bovine milk. It is worth noting that the high-abundance peptides (GLDIQKVAGT and IIAEKTKIPAVF) found in caprine LGB have been reported to have antimicrobial activity. Synthetic peptides of these 2 sequences inhibit Escherichia coli K12 (Almaas et al., 2011). These 2 peptides may also play an important role in preventing gastrointestinal infections.

The digestibility of LALBA and LGB showed a similar trend in bovine and caprine milk, although the digestibility rate differed between the two proteins, probably because of differences in protein structure between species. When comparing dimers in bovine and caprine LGB, the root mean square deviation value was different because of the distinct orientations between the 2 monomers in these 2 species (Crowther et al., 2014). It has been shown that LALBA in bovine and caprine milk have different binding capacities to monoclonal antibodies (Kaminogawa et al., 1989). The LALBA sequences in the 2 species are highly homogeneous, and differences in the binding capacity of LALBA are related to the difference in conformation. Therefore, the 
digestibility differences in LALBA between bovine and caprine milk serum is likely related to the differences in their conformation.

\section{Peptides Derived from Minor Milk Proteins}

In addition to the major proteins, numerous peptides originating from minor proteins were identified. Most peptides were derived from SAA1, GLYCAM1, LPO, PIGR, SPP1, BTN1A1, and LTF in both bovine and caprine milk serum. These proteins were resistant to gastrointestinal digestion, as indicated by the number of digested peptides compared with that of caseins. Digestibility rate is usually related to the protein AA sequence, protein structure, and posttranslational modification of the protein. Protein sequences with a high proline content are resistant to proteolysis, mainly because of the reduction in protein chain flexibility (Tagliazucchi et al., 2016). Gluten protein has lower digestibility than milk protein, in part because of its high proline content (Joye, 2019). It is generally believed that protein structure also affects its digestibility. For example, LGB is a dimeric globular protein. This stable conformation gives LGB high resistance to proteolysis. In contrast to LGB, casein molecules are more sensitive to proteolysis due to their flexible structure. The difference in the structure of these 2 proteins leads to their distinct digestibilities. Thermal treatment has a positive effect on the susceptibility of LGB to digestion (Reddy et al., 1988) because susceptible peptide bonds are exposed because of the heat-induced disruption to the structure. Proteins that undergo posttranslational modifications are more resistant to gastrointestinal digestion. The digestibility of milk protein concentrate increased with an increase in dephosphorylation (Liu et al., 2016). A high level of glycosylation in bovine LGB results in limited proteolysis compared with native bovine LGB (Corzo-Martínez et al., 2010).

Serum amyloid A is an acute phase protein in small ruminants (González et al., 2008); it protects newborns by preventing bacteria development (McDonald et al., 2001). The AA sequence of bovine SAA1 shows $94.6 \%$ homology with caprine SAA1. The high count of peptides derived from SAA1 in caprine sample was consistent with previous study (Hodgkinson et al., 2019). Caprine serum has a greater abundance of SAA1 compared with bovine (Lu et al., 2018), which may explain why larger number of peptides derived from SAA1 were identified in caprine samples.

Glycosylation-dependent cell adhesion molecule 1 is a secreted molecule detected in blood and milk. More peptides derived from GLYCAM1 were identified in both bovine gastric and intestinal samples than in caprine. The AA sequence of bovine GLYCAM1 shows $89.5 \%$ homology with caprine GLYCAM1. Bovine GLYCAM1 contains 5 partial phosphorylation sites and 3 glycosylation sites, whereas caprine GLYCAM1 contains 2 partial phosphorylation sites and 2 glycosylation sites (Girardet et al., 1995; Lister et al., 1998). The lower content of phosphorylation and glycosylation of caprine GLYCAM1 may explain why it was more sensitive to proteolysis. The differences in the digestibility of GLYCAM1 between bovine and caprine samples is probably related to the differences in AA sequences and posttranslational modifications.

Lactoperoxidase has antibacterial effect, which could protect newborns from infections (Goldman and Smith, 1973). The AA sequence of bovine LPO shows $96.5 \%$ homology with caprine LPO. It is a single polypeptide chain with several glycosylation sites (Sievers, 1981): 5 and 4 in bovine LPO and caprine LPO, respectively (B $\mathrm{S}$ et al., 2018). Because of the high homology between the 2 species, higher glycosylation of bovine LPO may explain why fewer peptides from LPO were identified in bovine gastric digesta.

Lactotransferrin is involved in several biological events, including transportation of iron ions, bacteriostatic effects, and constitution of the innate defense system. The AA sequence of bovine LTF shows $92.2 \%$ homology with caprine LTF. Bovine and caprine LTF shared about $90 \%$ of their 3-dimensional structure (Sreedhara et al., 2010). Lactotransferrin is also a glycoprotein. Although bovine and caprine LTF have the same number of potential glycosylation sites (Baker and Baker, 2009), some differences do exist in LTF glycosylation pattern between these 2 species. For instance, caprine LTF contains fewer sialylated $N$-glycans (Le Parc et al., 2014). A previous study showed that glycans bound to LTF affect its digestibility (van Berkel et al., 1996). In addition, LTF has a strong iron-binding capacity and the combination of iron and LTF reduces its sensitivity to digestion (Troost et al., 2001). A previous study reported that the iron concentration differed in bovine and caprine milks (Bilandžić et al., 2015), and differences in bovine and caprine LTF structure may lead to different iron-binding capacities. All of these factors may cause different iron saturations of LTF between the 2 species, which affect the digestibility of LTF in bovine and caprine milk. In general, the AA sequence, 3-dimensional structure, glycosylation pattern, and iron strength may result in differences in LTF digestions between the 2 species.

Butyrophilin subfamily 1 member A1, a member of the immunoglobulin superfamily, is related to lipid synthesis and secretion. Bovine and caprine BTN1A1 share a high homology $(97.0 \%)$ of AA sequence. Both bovine and caprine BTN1A1 are known to be $N$-glycosylated. However, the different band in SDS-PAGE for bovine 
and caprine BTN1A1 after periodic acid-Schiff staining or immunoblotting indicates differences in carbohydrate content (Cebo et al., 2010). The different carbohydrate contents may explain why different number of peptides from BTN1A1 were detected in bovine and caprine gastric digesta.

In summary, our results suggest that the digestive profiles of proteins in bovine and caprine serum differ. The difference in the digestive profile of milk serum proteins may be caused by different (1) databases used for searching, (2) protein sequences, (3) posttranslational modification, such as glycosylation and phosphorylation, and (4) physiochemical properties of milk serum, including $\mathrm{pH}$ and ion strength. The difference in the digestibility of milk serum proteins between bovine and caprine species can be used to better understand the differences between these 2 species. These results may increase our understanding of the differences in digestibility of goat milk-based infant formula fortified with either goat milk serum or bovine milk serum.

\section{ACKNOWLEDGMENTS}

This work was supported by the National Natural Science Foundation of China (31801463), Natural Science Foundation of Jiangsu Province (BK20180612), Innovation and Exploration Project of State Key Laboratory of Food Science and Technology (SKLF-ZZA-201907), and the National First-class Discipline Program of Food Science and Technology (JUFSTR20180201). The authors report no conflicts of interest.

\section{REFERENCES}

Almaas, H., A.-L. Cases, T. G. Devold, H. Holm, T. Langsrud, L. Aabakken, T. Aadnoey, and G. E. Vegarud. 2006. In vitro digestion of bovine and caprine milk by human gastric and duodenal enzymes. Int. Dairy J. 16:961-968. https://doi.org/10.1016/j.idairyj.2005.10 .029 .

Almaas, H., E. Eriksen, C. Sekse, I. Comi, R. Flengsrud, H. Holm, E. Jensen, M. Jacobsen, T. Langsrud, and G. E. Vegarud. 2011. Antibacterial peptides derived from caprine whey proteins, by digestion with human gastrointestinal juice. Br. J. Nutr. 106:896-905. https://doi.org/10.1017/S0007114511001085.

B S, G. K., P. M. Reddy, and S. Kottekad. 2018. Comparative sitespecific $N$-glycosylation analysis of lactoperoxidase from buffalo and goat milk using RP-UHPLC-MS/MS reveals a distinct glycan pattern. J. Agric. Food Chem. 66:11492-11499. https://doi.org/10 .1021/acs.jafc.8b03243.

Baker, E. N., and H. M. Baker. 2009. A structural framework for understanding the multifunctional character of lactoferrin. Biochimie 91:3-10. https://doi.org/10.1016/j.biochi.2008.05.006.

Bilandžić, N., M. Sedak, M. Đokić, and Đ. Božić. 2015. Determination of macro-and microelements in cow, goat, and human milk using inductively coupled plasma optical emission spectrometry. Spectrosc. Lett. 48:677-684. https://doi.org/10.1080/00387010 .2014.962704.

Brodkorb, A., L. Egger, M. Alminger, P. Alvito, R. Assunção, S. Ballance, T. Bohn, C. Bourlieu-Lacanal, R. Boutrou, F. Carrière, A. Clemente, M. Corredig, D. Dupont, C. Dufour, C. Edwards, M.
Golding, S. Karakaya, B. Kirkhus, S. Le Feunteun, U. Lesmes, A. Macierzanka, A. R. Mackie, C. Martins, S. Marze, D. J. McClements, O. Ménard, M. Minekus, R. Portmann, C. N. Santos, I. Souchon, R. P. Singh, G. E. Vegarud, M. S. J. Wickham, W. Weitschies, and I. Recio. 2019. INFOGEST static in vitro simulation of gastrointestinal food digestion. Nat. Protoc. 14:991-1014. https://doi.org/10.1038/s41596-018-0119-1.

Cebo, C., H. Caillat, F. Bouvier, and P. Martin. 2010. Major proteins of the goat milk fat globule membrane. J. Dairy Sci. 93:868-876. https://doi.org/10.3168/jds.2009-2638.

Chatterton, D. E., D. N. Nguven, S. B. Bering, and P. T. Sangild. 2013. Anti-inflammatory mechanisms of bioactive milk proteins in the intestine of newborns. Int. J. Biochem. Cell Biol. 45:17301747. https://doi.org/10.1016/j.biocel.2013.04.028.

Clark, S., and M. B. Moro García. 2017. A 100-year review: Advances in goat milk research. J. Dairy Sci. 100:10026-10044. https://doi .org/10.3168/jds.2017-13287.

Corzo-Martínez, M., A. C. Soria, J. Belloque, M. Villamiel, and F. J. Moreno. 2010. Effect of glycation on the gastrointestinal digestibility and immunoreactivity of bovine $\beta$-lactoglobulin. Int. Dairy J. 20:742-752. https://doi.org/10.1016/j.idairyj.2010.04.002.

Crowther, J. M., M. Lassé, H. Suzuki, S. A. Kessans, T. S. Loo, G. E. Norris, A. J. Hodgkinson, G. B. Jameson, and R. C. Dobson. 2014. Ultra-high resolution crystal structure of recombinant caprine $\beta$-lactoglobulin. FEBS Lett. 588:3816-3822. https://doi.org/ 10.1016/j.febslet.2014.09.010.

Dallas, D. C., A. Guerrero, N. Khaldi, R. Borghese, A. Bhandari, M. A. Underwood, C. B. Lebrilla, J. B. German, and D. Barile. 2014. A peptidomic analysis of human milk digestion in the infant stomach reveals protein-specific degradation patterns. J. Nutr. 144:815-820. https://doi.org/10.3945/jn.113.185793.

Dallas, D. C., A. Guerrero, N. Khaldi, P. A. Castillo, W. F. Martin, J. T. Smilowitz, C. L. Bevins, D. Barile, J. B. German, and C. B. Lebrilla. 2013. Extensive in vivo human milk peptidomics reveals specific proteolysis yielding protective antimicrobial peptides. J. Proteome Res. 12:2295-2304. https://doi.org/10.1021/pr400212z.

de Wit, J. 1998. Nutritional and functional characteristics of whey proteins in food products. J. Dairy Sci. 81:597-608. https://doi .org/10.3168/jds.S0022-0302(98)75613-9.

Dupont, D. 2017. Peptidomic as a tool for assessing protein digestion. Curr. Opin. Food Sci. 16:53-58. https://doi.org/10.1016/j .cofs.2017.08.001.

Dupont, D., G. Mandalari, D. Mollé, J. Jardin, O. Rolet-Répécaud, G. Duboz, J. Léonil, C. E. Mills, and A. R. Mackie. 2010. Food processing increases casein resistance to simulated infant digestion. Mol. Nutr. Food Res. 54:1677-1689. https://doi.org/10.1002/mnfr .200900582 .

Girardet, J. M., B. Coddeville, Y. Plancke, G. Strecker, S. Campagna, G. Spik, and G. Linden. 1995. Structure of glycopeptides isolated from bovine milk component PP3. Eur. J. Biochem. 234:939-946. https://doi.org/10.1111/j.1432-1033.1995.939_a.x.

Goldman, A. S., and C. W. Smith. 1973. Host resistance factors in human milk. J. Pediatr. 82:1082-1090. https://doi.org/10.1016/ S0022-3476(73)80453-6.

González, F. H., F. Tecles, S. Martínez-Subiela, A. Tvarijonaviciute, L. Soler, and J. J. Cerón. 2008. Acute phase protein response in goats. J. Vet. Diagn. Invest. 20:580-584. https://doi.org/10.1177/ 104063870802000507.

Hernández-Castellano, L. E., A. M. Almeida, J. Renaut, A. Argüello, and N. Castro. 2016. A proteomics study of colostrum and milk from the two major small ruminant dairy breeds from the $\mathrm{Ca}$ nary Islands: A bovine milk comparison perspective. J. Dairy Res. 83:366-374. https://doi.org/10.1017/S0022029916000273.

Hodgkinson, A. J., O. A. Wallace, I. Boggs, M. Broadhurst, and C. G. Prosser. 2018. Gastric digestion of cow and goat milk: Impact of infant and young child in vitro digestion conditions. Food Chem. 245:275-281. https://doi.org/10.1016/j.foodchem.2017.10.028.

Hodgkinson, A. J., O. A. Wallace, G. Smolenski, and C. G. Prosser. 2019. Gastric digestion of cow and goat milk: Peptides derived from simulated conditions of infant digestion. Food Chem. 276:619-625. https://doi.org/10.1016/j.foodchem.2018.10.065. 
Ingham, B., A. Smialowska, N. Kirby, C. Wang, and A. Carr. 2018. A structural comparison of casein micelles in cow, goat and sheep milk using X-ray scattering. Soft Matter 14:3336-3343. https://doi .org/10.1039/C8SM00458G.

Joye, I. 2019. Protein digestibility of cereal products. Foods 8:199. https://doi.org/10.3390/foods8060199.

Kaminogawa, S., M. Shimoda, J.-I. Kurisaki, and K. Yamauchi. 1989. Application of a monoclonal antibody to a comparative study of $\alpha$-lactalbumins from various species. J. Dairy Sci. 72:1124-1129. https://doi.org/10.3168/jds.S0022-0302(89)79214-6.

Le Parc, A., D. C. Dallas, S. Duaut, J. Leonil, and D. Barile. 2014. Characterization of goat milk lactoferrin N-glycans and comparison with the $N$-glycomes of human and bovine milk. Electrophoresis 35:1560-1570. https://doi.org/10.1002/elps.201300619.

Liao, Y., R. Alvarado, B. Phinney, and B. Lönnerdal. 2011. Proteomic characterization of human milk whey proteins during a twelvemonth lactation period. J. Proteome Res. 10:1746-1754. https:// doi.org/10.1021/pr101028k.

Lister, I. M., L. Rasmussen, L. Johnsen, L. Møller, T. Petersen, and E. Sørensen. 1998. The primary structure of caprine PP3: Amino acid sequence, phosphorylation, and glycosylation of component PP3 from the proteose-peptone fraction of caprine milk. J. Dairy Sci. 81:2111-2115. https://doi.org/10.3168/jds.S0022-0302(98)75786 $-8$.

Liu, D., Y. Wang, Y. Yu, J. Hu, N. Lu, J. M. Regenstein, M. Wang, and P. Zhou. 2016. Effects of enzymatic dephosphorylation on infant in vitro gastrointestinal digestibility of milk protein concentrate. Food Chem. 197:891-899. https://doi.org/10.1016/j .foodchem.2015.11.074.

Lu, J., T. van Hooijdonk, S. Boeren, J. Vervoort, and K. Hettinga. 2014. Identification of lipid synthesis and secretion proteins in bovine milk. J. Dairy Res. 81:65-72. https://doi.org/10.1017/ S0022029913000642.

Lu, J., S. Zhang, L. Liu, X. Pang, C. Ma, S. Jiang, and J. Lv. 2018. Comparative proteomics analysis of human and ruminant milk serum reveals variation in protection and nutrition. Food Chem. 261:274-282. https://doi.org/10.1016/j.foodchem.2018.04.065.

Madureira, A. R., C. I. Pereira, A. M. Gomes, M. E. Pintado, and F. X. Malcata. 2007. Bovine whey proteins - Overview on their main biological properties. Food Res. Int. 40:1197-1211. https:// doi.org/10.1016/j.foodres.2007.07.005.

Mayer, H. K., and G. Fiechter. 2012. Physical and chemical characteristics of sheep and goat milk in Austria. Int. Dairy J. 24:57-63. https://doi.org/10.1016/j.idairyj.2011.10.012.

McDonald, T. L., M. A. Larson, D. R. Mack, and A. Weber. 2001. Elevated extrahepatic expression and secretion of mammary-associated serum amyloid A 3 (M-SAA3) into colostrum. Vet. Immunol. Immunopathol. 83:203-211. https://doi.org/10.1016/S0165 $-2427(01) 00380-4$.

Mulet-Cabero, A.-I., A. R. Mackie, P. J. Wilde, M. A. Fenelon, and A. Brodkorb. 2019. Structural mechanism and kinetics of in vitro gastric digestion are affected by process-induced changes in bovine milk. Food Hydrocoll. 86:172-183. https://doi.org/10.1016/ j.foodhyd.2018.03.035.

Nielsen, P. M., D. Petersen, and C. Dambmann. 2001. Improved method for determining food protein degree of hydrolysis. J. Food Sci. 66:642-646. https://doi.org/10.1111/j.1365-2621.2001.tb04614.x.

Nielsen, S. D., R. L. Beverly, Y. Qu, and D. C. Dallas. 2017. Milk bioactive peptide database: A comprehensive database of milk protein-derived bioactive peptides and novel visualization. Food Chem. 232:673-682. https://doi.org/10.1016/j.foodchem.2017.04 .056 .

Nielsen, S. D., R. L. Beverly, M. A. Underwood, and D. C. Dallas. 2018. Release of functional peptides from mother's milk and fortifier proteins in the premature infant stomach. PLoS One 13:e208204. https://doi.org/10.1371/journal.pone.0208204.
Nilsson, M., J. J. Holst, and I. M. Björck. 2007. Metabolic effects of amino acid mixtures and whey protein in healthy subjects: Studies using glucose-equivalent drinks. Am. J. Clin. Nutr. 85:996-1004. https://doi.org/10.1093/ajcn/85.4.996.

Picariello, G., P. Ferranti, O. Fierro, G. Mamone, S. Caira, A. Di Luccia, S. Monica, and F. Addeo. 2010. Peptides surviving the simulated gastrointestinal digestion of milk proteins: Biological and toxicological implications. J. Chromatogr. B Analyt. Technol. Biomed. Life Sci. 878:295-308. https://doi.org/10.1016/j.jchromb 2009.11.033.

Reddy, I. M., N. K. Kella, and J. E. Kinsella. 1988. Structural and conformational basis of the resistance of. beta.-lactoglobulin to peptic and chymotryptic digestion. J. Agric. Food Chem. 36:737-741. https://doi.org/10.1021/jf00082a015.

Selvaggi, M., V. Laudadio, C. Dario, and V. Tufarelli. 2014. Major proteins in goat milk: An updated overview on genetic variability. Mol. Biol. Rep. 41:1035-1048. https://doi.org/10.1007/s11033-013 -2949-9.

Sievers, G. 1981. Structure of milk lactoperoxidase: Evidence for a single polypeptide chain. FEBS Lett. 127:253-256. https://doi.org/10 .1016/0014-5793(81)80218-9.

Sreedhara, A., R. Flengsrud, T. Langsrud, P. Kaul, V. Prakash, and G. E. Vegarud. 2010. Structural characteristic, $\mathrm{pH}$ and thermal stabilities of apo and holo forms of caprine and bovine lactoferrins. Biometals 23:1159-1170. https://doi.org/10.1007/s10534-010 -9366-5.

Su, M.-Y., M. Broadhurst, C.-P. Liu, J. Gathercole, W.-L. Cheng, X.Y. Qi, S. Clerens, J. Dyer, L. Day, and B. Haigh. 2017. Comparative analysis of human milk and infant formula derived peptides following in vitro digestion. Food Chem. 221:1895-1903. https:// doi.org/10.1016/j.foodchem.2016.10.041.

Tagliazucchi, D., A. Helal, E. Verzelloni, A. Bellesia, and A. Conte. 2016. Composition and properties of peptides that survive standardised in vitro gastro-pancreatic digestion of bovine milk. Int Dairy J. 61:196-204. https://doi.org/10.1016/j.idairyj.2016.06 .002 .

Tagliazucchi, D., S. Martini, S. Shamsia, A. Helal, and A. Conte. 2018. Biological activities and peptidomic profile of in vitro-digested cow, camel, goat and sheep milk. Int. Dairy J. 81:19-27. https:// doi.org/10.1016/j.idairyj.2018.01.014.

Tamime, A., M. Wszolek, R. Božanić, and B. Özer. 2011. Popular ovine and caprine fermented milks. Small Rumin. Res. 101:2-16. https://doi.org/10.1016/j.smallrumres.2011.09.021.

Troost, F. J., J. Steijns, W. H. Saris, and R.-J. M. Brummer. 2001. Gastric digestion of bovine lactoferrin in vivo in adults. J. Nutr. 131:2101-2104. https://doi.org/10.1093/jn/131.8.2101.

van Berkel, P. H. C. V., H. A. van Veen, M. E. Geerts, H. A. de Boer, and J. H. Nuijens. 1996. Heterogeneity in utilization of N-glycosylation sites Asn624 and Asn138 in human lactoferrin: A study with glycosylation-site mutants. Biochem. J. 319:117-122.

Ye, A., J. Cui, E. Carpenter, C. Prosser, and H. Singh. 2019. Dynamic in vitro gastric digestion of infant formulae made with goat milk and cow milk: Influence of protein composition. Int. Dairy J. 97:76-85. https://doi.org/10.1016/j.idairyj.2019.06.002.

\section{ORCIDS}

Ying Ma๑ https://orcid.org/0000-0003-4462-175X Binsong Han () https://orcid.org/0000-0002-9033-8931 Lina Zhang @ https://orcid.org/0000-0002-3039-1597 Peng Zhou @ https://orcid.org/0000-0002-6665-3800 